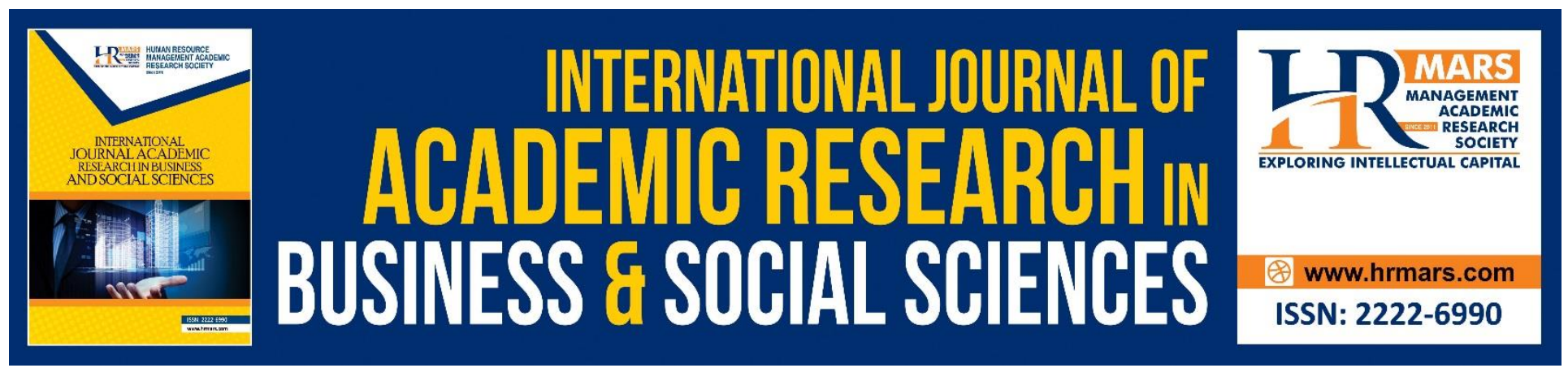

\title{
Examining Mediating Role of Self-Efficacy on Undergraduates' Perceived Employability
}

Hon Jie Chow, Siew Chin Wong, Chui Seong Lim

To Link this Article: http://dx.doi.org/10.6007/IJARBSS/v9-i6/5929

DOI: $10.6007 /$ IJARBSS/v9-i6/5929

Received: 03 April 2019, Revised: 29 May 2019, Accepted: 1 Jun 2019

Published Online: 24 June 2019

In-Text Citation: (Chow, Wong, \& Lim, 2019)

To Cite this Article: Chow, H. J., Wong, S. C., \& Lim, C. S. (2019). Examining Mediating Role of Self-Efficacy on ndergraduates' Perceived Employability. International Journal of Academic Research Business and Social Sciences, 9(6), 135-158.

\section{Copyright: (C) 2019 The Author(s)}

Published by Human Resource Management Academic Research Society (www.hrmars.com)

This article is published under the Creative Commons Attribution (CC BY 4.0) license. Anyone may reproduce, distribute, translate and create derivative works of this article (for both commercial and non-commercial purposes), subject to full attribution to the original publication and authors. The full terms of this license may be seen

at: $\underline{\text { http://creativecommons.org/licences/by/4.0/legalcode }}$

Vol. 9, No. 6, 2019, Pg. 135 - 158

http://hrmars.com/index.php/pages/detail/IJARBSS

JOURNAL HOMEPAGE

Full Terms \& Conditions of access and use can be found at http://hrmars.com/index.php/pages/detail/publication-ethics 


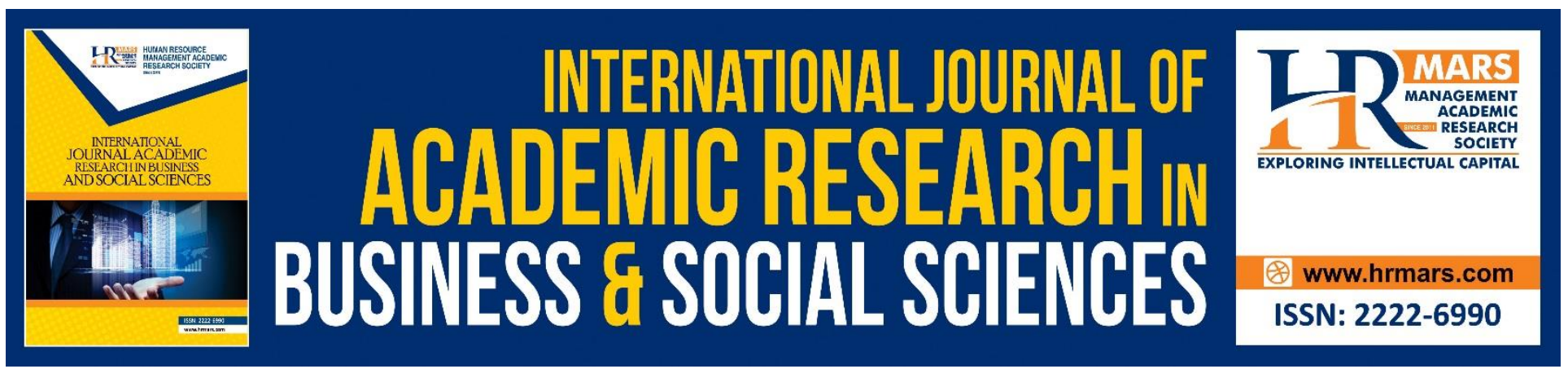

\title{
Examining Mediating Role of Self-Efficacy on Undergraduates' Perceived Employability
}

\section{Hon Jie Chow, Siew Chin Wong, Chui Seong Lim \\ Faculty of Business, Economics and Accounting and Economic \\ HELP University, 50490 Kuala Lumpur, Malaysia \\ Email: jacobchow0107@gmail.com, sc.wong@help.edu.my_chuiseong.lim@help.edu.my}

\begin{abstract}
The aim of the present work is to examine the relationship between perceived social supports, selfmanaged career behaviour, and perceived employability of undergraduates at both public and private Malaysian universities. The study also examines the mediating effect of self-efficacy on the perceived employability of undergraduates. The research sample was 267 undergraduates from public and private universities in Malaysia. Partial Least Squares Structural Equation Modelling (PLSSEM) is used to perform the data analysis in present study. The result showed that both self-managed career behaviour and self-efficacy correlate significantly with perceived employability among undergraduates. Additionally, the findings found that self-efficacy mediates the relationship between self-managed career behaviour and perceived employability. However, there is no significant positive correlation between perceived social supports and perceived employability. Similarly, there is no mediating effect of self-efficacy on the relationship between perceived social supports and perceived employability. This study contributes to the knowledge base that focuses on a better understanding of the perceived employability of the younger generation via the existing employability model.
\end{abstract}

Keywords: Perceived Social Supports, Self-managed Career Behavior, Self-efficacy, Perceived Employability and Undergraduates.

\section{Introduction}

The best way to support undergraduates in a career is to align the curriculum planning to the needs of the labor market by providing not only theoretical but also relevant practical experience to meet the expectations of future employers. It is important to further examine the undergraduates' perception of their employability in order to ensure the employability of undergraduates. According to the International Labor Organization (2018), the youth unemployment rate in Malaysia was $10.85 \%$ in 2017, compared to other countries such as Singapore (4.6\%), Thailand (5.94\%) and the Philippines (6.77\%) \%), China (10.8\%), India (10.5\%) and Vietnam (7\%). The graduate unemployment rate in 2017 is about 20,4000 , which corresponds to $40.7 \%$ of the unemployment rate in Malaysia (MIDF, 2018). 
The statistical analysis has raised a serious question about youth unemployment in Malaysia. The problem of skill mismatch is affecting fresh graduates' inability to secure employment opportunities (Tuah, 2018). Previous studies have found that organizations place a high priority on graduates with problem-solving skills, network management and multilingualism (Niemela, 2016; Thang \& Wongsurawat, 2016).

Empirical studies postulated that undergraduates who proactively develop their professional skills at the university are more likely to secure employment opportunities, as employers are interested in recruiting graduates with adequate competencies (Poon, 2012; Su \& Zhang, 2015). However, many graduates are skilled in answering questions during the exam but have failed to apply the theoretical knowledge learned to practical daily work requirements (Poon, 2012). Furthermore, university undergraduates are unaware of the phenomenon in the real world of work and are maladaptive to the transition from academic to work (Shafie \& Nayan, 2010). Previous pieces of literature have spent a great deal of energy to help understand the employability of the organisation's employees (De Cuyper \& De Witte, 2010, Kinnunen, Makikangas, Mauno, Siponen, \& Natti, 2011; Chiesa, Fazi, Guglielmi \& Mariani, 2018). However, the understanding of perceived employability among undergraduates remains limited, especially in the Malaysian context. In addition, previous studies indicated that individuals with adequate social support are more likely to have higher emotional intelligence (Hogan et al., 2010, Montes-Berges \& Augusto, 2007). However, there is still a lack of research on the relationship between social support and employability. Therefore, the current study aims to fill in the gaps by further examining the undergraduates' perception of their employability, particularly the relationship between perceived social support, self-managed career behavior, and perceived employability with the mediator of self-efficacy among undergraduates.

\section{Literature Review}

\section{Perceived Employability}

According to Rothwell, Herbert, and Rothwell (2008), perceived employability is defined as the subjective perception of an individual's ability to obtain sustainable employment based on their own qualifications and self-perceived personal abilities. Yorke and Knight (2004) argue that employability encompasses four major interlocked constructs, which includes understanding, skills, efficacy beliefs, and metacognition. This is often referred to as USEM's employability model. Rothwell et al. (2008) improved the understanding of the self-perceived employability model by succinctly highlighting four key dimensions to examine the concept of perceived employability. They found that the reputation of the university, the field of study, the state of the external labor market, and self-confidence would affect the perception of undergraduate students with respect to their future employability. In addition, Hillage and Pollard (1998) developed a framework to explain individual employability assets (ability, skill and knowledge), deployment (career self-management, job search skills and strategic approach), presentations (writing resumes, qualifications, work experience and Interview technique) and job acquisition skills are important factors influencing individual employability. 
INTERNATIONAL JOURNAL OF ACADEMIC RESEARCH IN BUSINESS AND SOCIAL SCIENCES

Vol. 9, No. 6, June, 2019, E-ISSN: 2222-6990 (C) 2019 HRMARS

\section{Underpinning Theories}

\section{CareerEDGE Model}

In the current study, the CareerEDGE model (shown in Figure 2.1) was used to determine the influence of self-managed career behavior and perceived social support on undergraduates perceived employability. The CareerEDGE model explains that career development learning, work and life experiences, degree subject knowledge, generic skills and emotional intelligence are factors that influence graduates' employability (Pool \& Sewell, 2007). Watt (2006) explained that career development learning includes three main dimensions, such as career education learning, career selfmanagement, and career management skills. The CareerEDGE model focuses on career education learning in their construct of career development learning, which refers to planned curriculum activities designed to develop undergraduate self-awareness, opportunity awareness, decisionmaking learning, and transitional learning to improve their employability. Therefore, the motivation of this study is to further investigate the effect of career self-management behavior on undergraduates self-perceived employability, because career self-management behavior is part of the construct of career development learning (Watt, 2006). In addition, the CareerEDGE model also proposes emotional intelligence is one of the factors that influence individual employability. This study further developed the CareerEDGE model by investigating the factor of social support in developing individual's employability. Previous studies have shown that individuals with adequate social support tend to develop high emotional intelligence (Hogan et al., 2010; Montes-Berges \& Augusto, 2007). Therefore, this study recognizes and believes that social support is an important subset which affects a person's emotional intelligence, as described in the CareerEDGE model (Pool \& Sewell, 2007). 


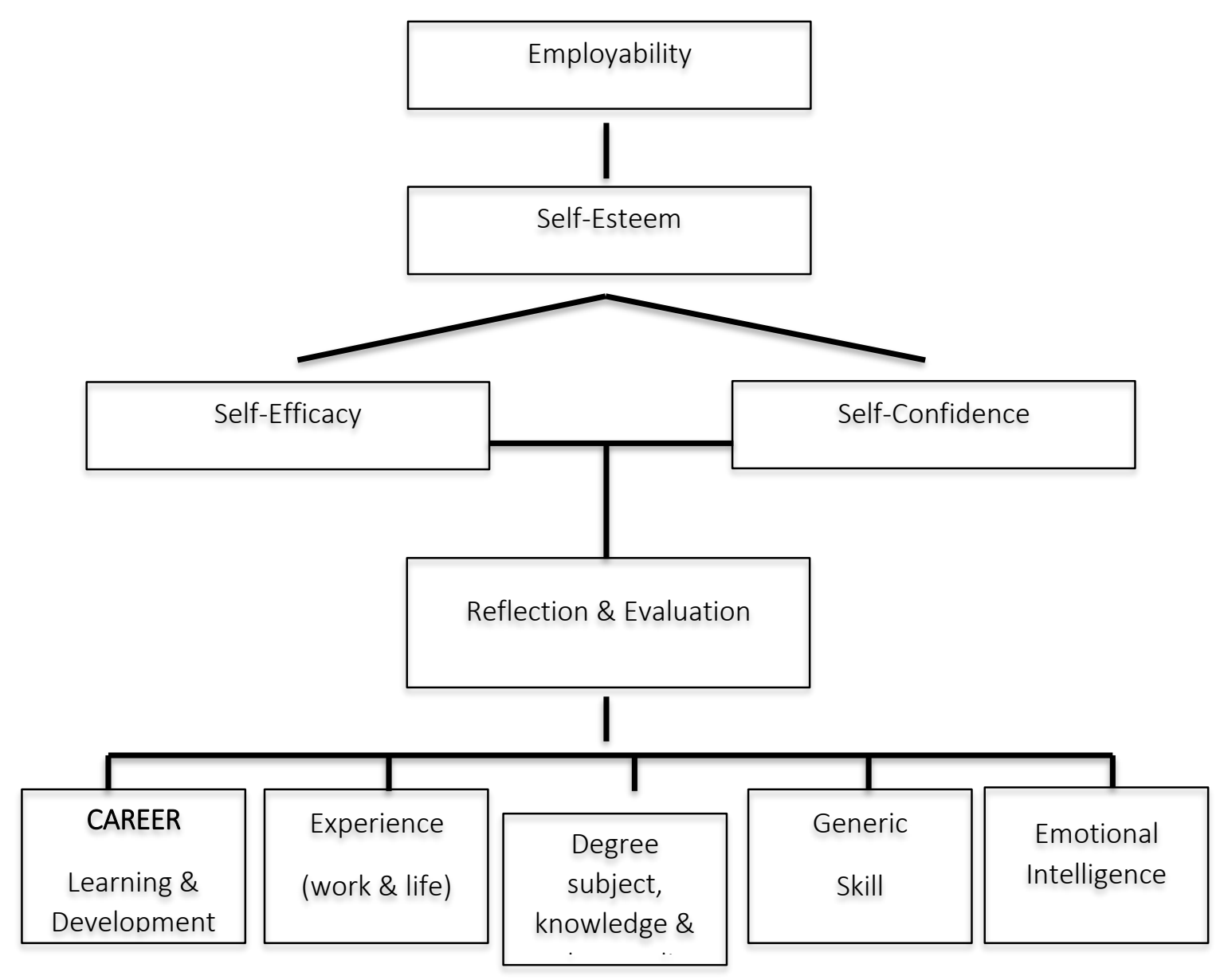

Figure 2.1 CareerEDGE Model

\section{Social Cognitive Career Theory}

Social cognitive career theory (shown in Figure 2.2) is also the underpinning theory supporting the current research framework. SCCT is used to study efficacy beliefs, outcome expectations and goal mechanisms, and to explain how these three factors are influenced by person's input and contextual background (Lent, Brown, \& Hackett, 1994). Person input refers to individual difference variables such as predispositions, abilities, gender, race, ethnicity, and health status. The current research conceptualizes self-managed career behavior as individual difference variables, as self-management behavior is seen as an individual-related factor that influences the career development process. This proactive behavior may potentially influence the desired outcome. For example, undergraduates who self-manage/proactively improve their competencies (predisposition/attitude) are more likely to secure employment (the desired outcome) when they graduate. Therefore, this study 
INTERNATIONAL JOURNAL OF ACADEMIC RESEARCH IN BUSINESS AND SOCIAL SCIENCES

Vol. 9, No. 6, June, 2019, E-ISSN: 2222-6990 @ 2019 HRMARS

hypothesized a positive correlation between self-managed career behavior and undergraduates employability.

In addition, Lent, Brown, and Hackett (1994) also stated that environmental influence (contextual background) could affect the career outcome or attainment. The previous study has often conceptualized perceived social support as the contextual background outlined in the SCCT model, which can motivate and encourage individuals to achieve desired outcomes (Dickinson, 2007; Isik, 2013; Wong \& Quek, 2015). Therefore, this study hypothesized that perceived social support (contextual background) will influence undergraduate's perceptions of employability (desired outcome or attainment). In addition, SCCT also posited that both a person input variable and contextual background affects an individual's self-efficacy beliefs, which then influence outcomes or attainment. According to the SCCT, this study hypothesises that self-efficacy acts as a mediator of the relationships, including (1) the relationship between self-managed career behaviour (person input) and perceived employability (outcome/attainments), and (2) relationships between perceived social support (contextual background) and perceived employability (outcome/attainments).

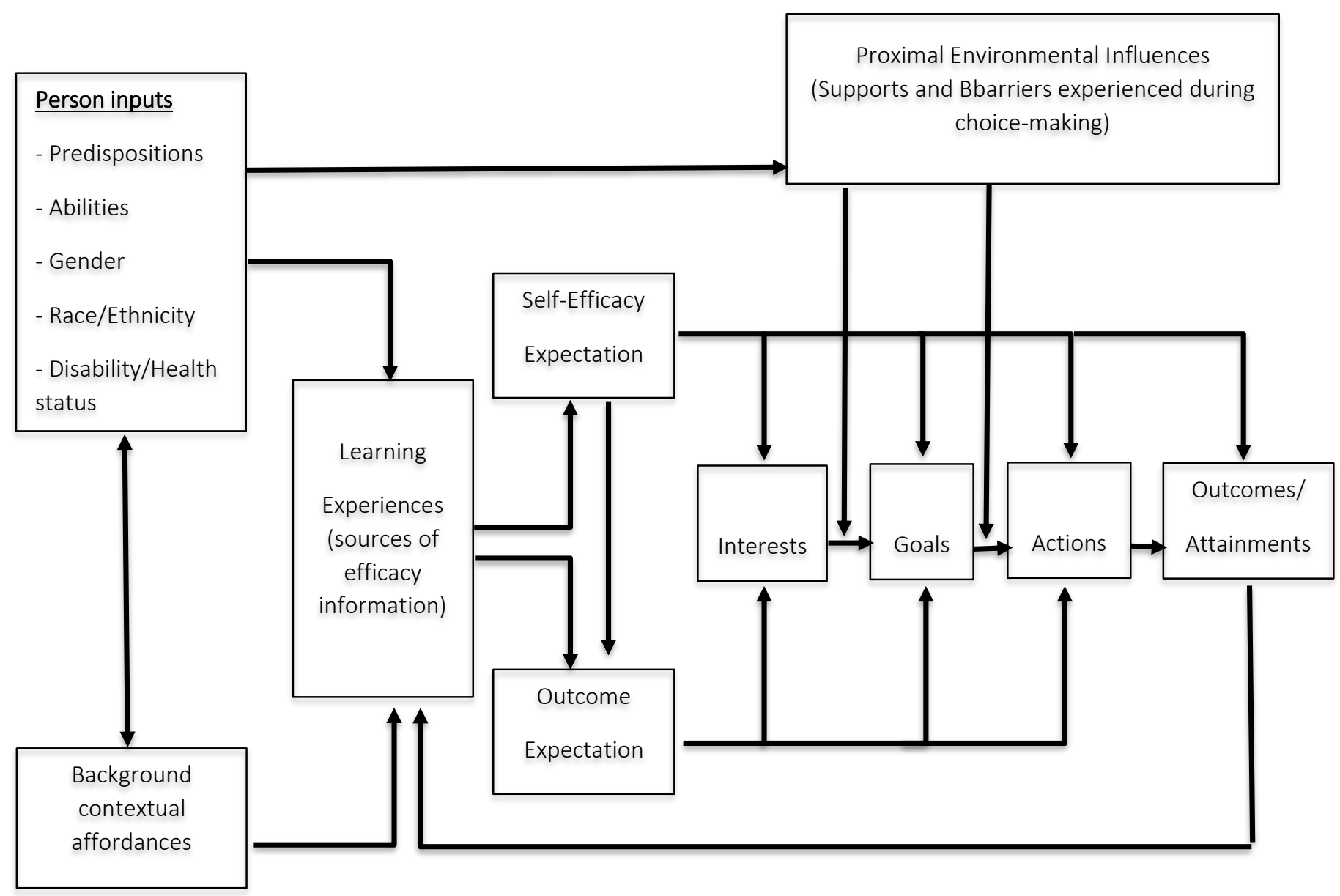

Figure 2.2 Social Cognitive Career Theory 


\section{Perceived Social Support}

Perceived social support is defined as the perception of people towards their received support from family, friends and significant others (Zimet, Dahlem, Zimet \& Farley, 1988). The social support of families, peers and significant others will be an important social capital or resource for undergraduates to seek employment opportunities or to promote future career success. Bourdieu (1986) refers to social capital as the sum of potential or actual resources obtained from social networks. People use the opportunities and benefits available in social networks to maximise their productivity (Bhandari \& Yasunobu, 2009). In addition, Bourdieu (1986) found that a person's social capital richness is significantly related to the broadness of his or her social network. As a result, individuals with a broader social network tend to have more resources, opportunities and support (Ryan, Sales, Tilki, \& Siara, 2008). This means that undergraduates' with a wide range of social networks tend to receive more social support, which can serve as a resource for their ability to improve their employability.

Previous studies have found that undergraduates prefer to seek career advice and support from university lecturers (Clements \& Kamau, 2018; Vargas, 2018). They found that university lecturers are accessible to them, and they were able to provide sufficient emotional support, professional career advice and constructive feedback to further improve the self-confidence and self-efficacy level of the undergraduate's (Fawehinmi \& Yahya, 2018). In addition, the previous study has shown that graduates who have received sufficient support from their peers such as seniors who have completed the university and the university's career centers will tend to improve their perception of employability (Donald, Ashleigh, \& Baruch, 2018). Therefore, the current research aims to further expand the past literature by studying the relationship between perceived social support and undergraduate has perceived employability.

\section{Self-Managed Career Behaviour}

The conceptualization of self-managed career behavior is adapted from Orpen (1994). Orpen (1994) defines self-managed career behavior or individual career management as the proactive behavior of the individuals by putting their personal efforts to advance their skills for a future career goal. Selfmanaged career behavior consists of two main constructs, career planning and career tactics (Orpen, 1994). Career planning includes the identification of a person's career goals and personal characteristics such as values, principles, strengths, and weaknesses to achieve a particular career goal. In addition, the achievement of career goals requires a proper implementation of planned strategies, which are called career tactics. Traditionally, high academic performance is expected to predict undergraduate employment (Gokuladas, 2011; Qenani, MacDougall, \& Sexton, 2014). However, recent research suggests that academic excellence alone does not predict the high employment rate of undergraduates, and other relevant factors, such as participation in extracurricular activities, communication skills, and other university learning experiences, contribute significantly to the employability of students (Niemela, 2016; Pinto \& Ramalheira, 2017; Sin, Tavares, \& Amaral, 2016). 
Previous research has shown that proactive self-managing career behaviour in universities, such as maximising university learning experiences, as part-time or participating in internship programs to gain work experience, may affect undergraduates' perception of employability (Wang \& Tsai, 2014; Rothwell, Jewell, \& Hardie, 2009). Empirical studies postulated that self-managed career behavior improves undergraduates' self-perception of employability (Qenani, MacDougall, \& Sexton, 2014). Individuals who self-managed career behavior adhere to a strong sense of responsibility to improve their professional skills (Bridgstock, 2009). For example, undergraduates with this positive attitude will seek more career information and actively participate in various personal development programs at the university. This attitude or behavior allows them to improve their self-efficacy beliefs and ultimately make them feel more able to secure employment opportunities when they graduate.

\section{Mediating Role of Self-Efficacy}

Self-efficacy is defined as the perceived ability or capability of the individual in performing certain tasks and achieving targeted goals (Bandura, 1986). Bandura suggested that individual's efficacy beliefs come from four important sources, such as mastery experience, vicarious experience, social persuasion and diversity receptivity (Bandura, 1986). Mastering experience refers to the individual's past performance achievements. The previous successful experience of completing a task can improve a person's level of self-efficacy because those successful experiences confirm the individual's ability. In addition, if others recognize his or her ability and capability to perform a course of action, individuals will have a high level of self-efficacy, which is called social persuasion. Bandura (1986) also suggested that the emotional state of the individual could improve the level of self-efficacy. People with positive emotional states often have strong beliefs in efficacy to achieve goals. Finally, vicarious experience refers to an individual's observation of others, who are usually personal role models. By observing other people's successful completion of a task, individuals tend to think that they have similar capabilities to achieve the same result.

Past research has shown that the full support of family members and others is essential for undergraduates to improve their self-efficacy, which allows them to obtain enough information, such as available job vacancies, the working style in a business organization and competencies required in a specific industry (Batistic \& Tymon, 2017; Potgieter, 2012). These career pieces of advice and information are critical for undergraduates to determine their current competency gaps and future job requirements/employment competency expectations. In addition, such information from social networks can motivate undergraduates to bridge the gap by engaging in various roles in the university to develop their skills and enhance their employability. Various forms of support will improve the level of self-efficacy of undergraduates and enable them to be more competent in achieving their career goals (Hui, Yuen, \& Chen, 2018).

A large corpus of literature focuses on the topic of career self-management behavior in different settings. Individuals with a high degree of self-esteem and confidence in their capabilities are more likely to take proactive measures to manage their behavior and achieve future career goals through employment opportunities (Potgieter, 2012). The SCCT model considers self-efficacy to be the mediator between person input and desired outcome achievement (Lent, Brown, \& Hackett, 1994). 
INTERNATIONAL JOURNAL OF ACADEMIC RESEARCH IN BUSINESS AND SOCIAL SCIENCES Vol. 9, No. 6, June, 2019, E-ISSN: 2222-6990 @ 2019 HRMARS

In other words, individuals who participate in self-regulating behaviors during university (conceptualized as person input) to improve their professional skills and abilities tend to perceive that they are more employable than others (conceptualized as desired outcome achievements) are. Therefore, current research predicts that self-efficacy can act as a mediator, influencing the relationship between perceived social support and self-managed career behavior, as well as the perceived employability of undergraduates.

Therefore, the hypotheses of the present study are:

H1: There is a significant positive relationship between perceived social support and perceived employability among undergraduates.

H2: There is a significant positive relationship between self-managed career behavior and perceived employability among undergraduates.

H3: There is a significant positive relationship between self-efficacy and perceived employability among undergraduates.

H4: Self-efficacy mediates the relationship between perceived social support and perceived employability among undergraduates.

H5: Self-efficacy mediates the relationship between self-managed career behavior and perceived employability among undergraduates.

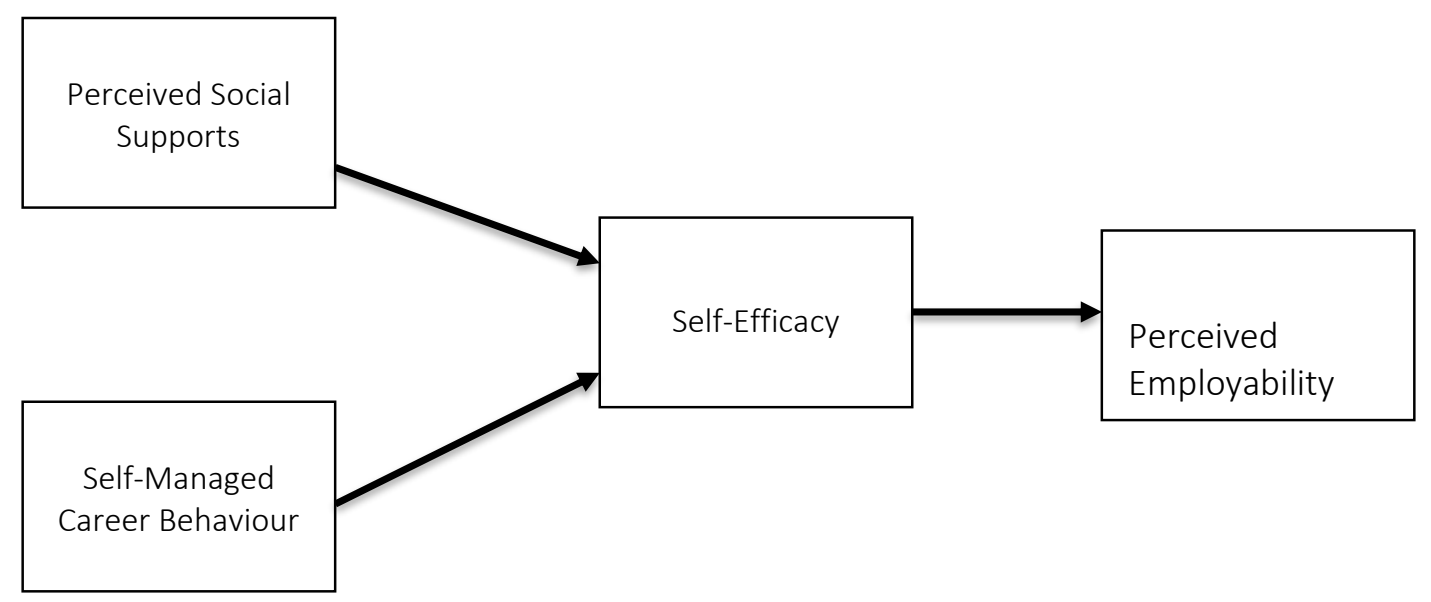

Figure 2.3 Current Research Framework

\section{Methodology}

\section{Population and Sample}

The purpose of this study is to examine the various factors that influence the perception of undergraduate employability. Therefore, the target population for this study is all undergraduates in Malaysia. In addition, according to the PLS-SEM sample size recommendation table, the current study required at least 22 participants to obtain $80 \%$ statistical power to detect at least a minimum of $50 \%$ $\mathrm{R}^{2}$ with a probability error of $1 \%$ (Cohen, 1992). However, a total of 267 participants were successfully enrolled in the study, of which $34.2 \%$ were male and $65.8 \%$ were female. Most of the participants 
INTERNATIONAL JOURNAL OF ACADEMIC RESEARCH IN BUSINESS AND SOCIAL SCIENCES Vol. 9, No. 6, June, 2019, E-ISSN: 2222-6990 @ 2019 HRMARS

came from private universities (65.4\%) and the remaining $34.6 \%$ were from public universities. Therefore, the sample size requirements of the current study are met.

\section{Instrumentation}

All the questionnaires used in the current study are from past pieces of literature. The questionnaire was adopted and adapted to ensure that the questions are appropriate for the current study. All questions consisted of a 5-point Likert scale, while 1 referred to "Strongly Disagree", 2 to "Disagree", 3 to "Neither Agree nor Disagree", 4 to "Agree" and finally 5 to "Strongly Agree". Perceived employability of undergraduates was accessed through the use of the employability scale developed by Rothwell, Herbert and Rothwell (2008). Examples of items include "Employers are eager to employ graduates from my university". The multidimensional perceived social support scale of Zimet, Dahlem, Zimet and Farley (1998) was used in this current research to measure variables of perceived social support. The scale was developed to examine the individual's perception of received social support from family, friends and significant others. An example of a problem is "I can count on my friends when something goes wrong." Self-managed career behaviour is measured by Orpen's (1994) by a seven-item scale of Individual Career Management Scale. This scale is intended to access the component of career planning and career tactics of an individual. Example of items included is "I have definite goals for my career over my lifetime". The current study uses the New General Self-Efficacy Scale (NGSE) developed by Chen, Gully, and Eden (2001) to measure the construct of self-efficacy. The sample of the question is "I will be able to achieve most of the goals that I have set for myself".

\section{Convergent Validity}

The Cronbach's Alpha value for perceived employability perceived social support, self-managed career behaviour and self-efficacy were $0.837,0.898,0.848$, and 0.892 , respectively, reflecting high internal consistency. In addition, current research ensures that there is sufficient convergent validity before data analysis. Convergent validity refers to whether the construct measurement can represent the construct itself (Hair, Hult, Ringle, \& Sarstedt, 2017). It is expected that there will be a positive intercorrelation between all the indicators in a similar construct because they reflect the same construct. To achieve sufficient convergent validity, Hair et al. (2017) suggested that each construct should achieve an average variance extraction (AVE) of at least 50\%. Table 3.1 describes the variables that yield sufficient AVE values, such as perceived social support (0.530), self-managed career behaviour (0.525), self-efficacy (0.571), and perceived employability (0.505). Therefore, the convergent validity requirements are met in the current study.

\section{Insert Table 3.1}

\section{Discriminant Validity}

Discriminant validity is to ensure that the constructs within similar frameworks are truly different from each other (Hair et al., 2017). In order to achieve sufficient discriminant validity, the square root of AVE must be greater than the latent variable correlation (Fornell \& Larcker, 1981). In addition, HTMT Criterion also confirmed the discriminant validity of different constructs, HTMT Criterion state that the value of HTMT should not exceed 0.85 (Kline, 2011). The discriminant validity of the study 
INTERNATIONAL JOURNAL OF ACADEMIC RESEARCH IN BUSINESS AND SOCIAL SCIENCES

Vol. 9, No. 6, June, 2019, E-ISSN: 2222-6990 (C) 2019 HRMARS

was determined by showing a value in which the confidence interval does not exceed 1, which indicates high discriminant validity. As shown in

Tables 3.2 and 3.3, the current study demonstrates sufficient discriminant validity.

\section{Insert Table 3.2 and Table 3.3}

\section{Result}

Current researchers use partial least square (PLS) path analysis for data analysis (as shown in Table 4.1 and Figure 4.1 ). This study found that $42.1 \%$ of perceived employability variance can be explained by perceived social support and self-managed career behavior $\left(R^{2}=0.421\right)$. In addition, current research indicates that perceived social support was not significantly positively correlated to perceived employability $(\beta=.083, p>.05)$, t-value $(1.337<2.33$, significant level $=5 \%)$. However, selfmanaged career behavior was significantly positively correlated to perceived employability $(\beta=.083$, $\mathrm{p}<.05)$, t-value $(1.337<2.33$, significant level $=5 \%)$. Therefore, $\mathrm{H} 1$ was rejected and $\mathrm{H} 2$ was accepted in the current study. In addition, 39\% of perceived employability variance can be explained by selfefficacy $\left(R^{2}=0.39\right)$. This study found that there was a significant positive correlation between selfefficacy and employability among undergraduates $(\beta=.358, p>.05)$, t-value $(5.227<2.33$, significant level $=5 \%$ ).

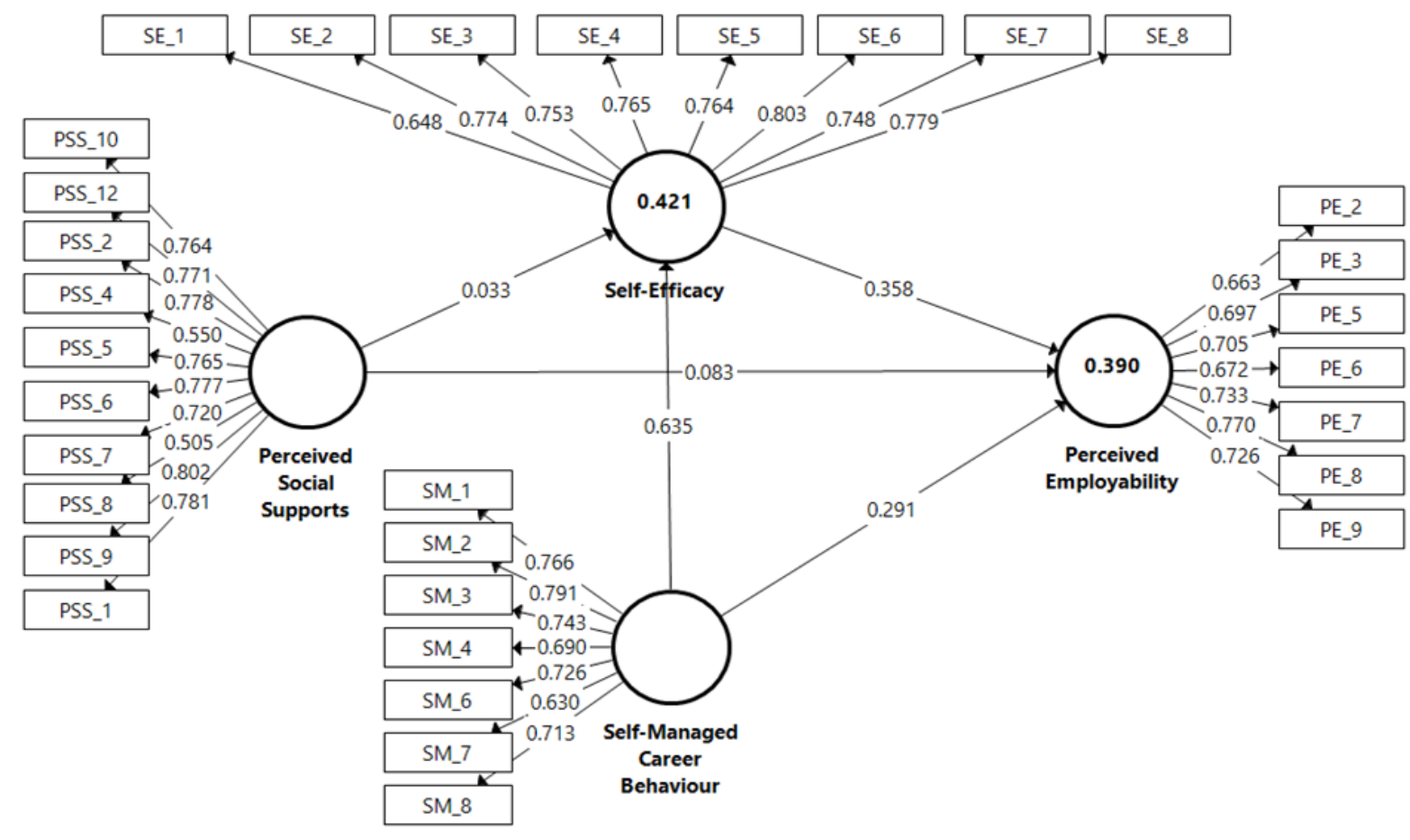

Figure 4.1 Result of Path Analysis (Structural Model)

Table 4.1 shows the $f^{2}$ values of different variables, such as perceived social support (0.009), selfmanaged career behaviour (0.074), and self-efficacy $(0.122)$. The results show that perceived social 
INTERNATIONAL JOURNAL OF ACADEMIC RESEARCH IN BUSINESS AND SOCIAL SCIENCES Vol. 9, No. 6, June, 2019, E-ISSN: 2222-6990 @ 2019 HRMARS

support, self-managed career behavior and self-efficacy variables have small effect on $\mathrm{R}^{2}$ that produces perceived employability. In addition, Table 4.1 also depicts the different $q^{2}$ values, namely perceived social support $\left(q^{2}=0.002\right)$, self-managed career behavior $\left(q^{2}=0.02\right)$ and self-efficacy $\left(q^{2}=\right.$ 0.07). The results of the study show that perceived social support, self-managed career behavior and self-efficacy variables have small effect on perceived employability.

\section{Insert Table 4.1}

This study is interested in exploring the mediating effects of self-efficacy on two direct relationships: (1) the relationship between perceived social support and perceived employability, and (2) the relationship between self-managed career behavior and perceived employability. The bootstrapping analysis demonstrated a total of two indirect effects in total, as shown in Table 4.2. Firstly, the indirect effect of self-efficacy, $\beta=0.012$, was not significant at t-values of 0.583 , with a $p$-value of 0.573 . Preacher and Hayes (2008) suggested that the indirect effect of $0.012,95 \%$ Boot Cl: $[\mathrm{LL}=-0.031, \mathrm{UL}$ $=0.049$ ] which straddled 0 in between indicating that self-efficacy does not mediate the relationship between perceived social support and perceived employability. Secondly, the indirect effect of selfefficacy, $\beta=0.228$ was significant at a $t$-value of 4.684 , with a $p$-value $<0.01$. Preacher and Hayes (2008) suggested an indirect effect of $0.228,95 \%$ Boot $\mathrm{Cl}$ : [ $\mathrm{LL}=-0.135, \mathrm{UL}=0.326$, which does not straddle a zero in between, indicating that self-efficacy mediates the relationship between selfmanaged career behavior and perceived employability. Therefore, hypothesis 4 is rejected, and selfefficacy is not a mediator for perceived social support and perceived employability. However, hypothesis 5 was based on the fact that the relationship between self-managed career behavior and perceived employability would be mediated by self-efficacy.

\section{Insert Table 4.2}

\section{Discussion}

The findings of this study do not support the notion that high perceived social support can improve the perception of employability among undergraduate. This means that the support from families, peers and significant others does not contribute to the perception of employability among undergraduates. Various empirical studies have indicated that self-awareness, job search attitude, identification of career goals and career action implementation are important factors in shaping a person's employability (Niemela, 2016; Orpen, 1994, Su \& Zhang, 2015; Thang \& Wongsurawat, 2016), however, social supports may not directly contribute to these factors and improve the perceived employability of undergraduates. The employability of a person depends not only on the attributes of the person, but also on the perceived potential in the acquisition of employment (Ballout, 2007). The ability to find a job depends both on intrinsic and extrinsic factors (Baruch \& Bozionelos, 2011; Wille, De Fruyt, \& Feys, 2013). Receiving adequate social support does not guarantee the perceived ability or capability of an individual to obtain and acquire a job (Tran, 2013). Some researchers have argued that social support would become essential in the event of emotional exhaustion, burnout or other psychological distress (Abarghuei \& Ghavam 2016; McLuckie et al., 2018). Social supports play a vital role in providing emotional support to individuals and improving their psychological state (Li, Han, Wang, Sun, \& Cheng, 2018). As a result, social supports help 
undergraduate students to be mentally prepared to acquire new skills to improve their employability, without directly improving their self-perceived employability.

The present study showed that there was a significant positive relationship between self-managed career behavior and perceived employability among undergraduates and $\mathrm{H}^{2}$ was supported. The results showed that undergraduates with self-managed career behaviors tend to perceive themselves as more able to work. These research findings are consistent with previous studies that indicated that self-managed career behavior improves the employability perception of undergraduates (Bridgstock, 2009; Clement \& Kamau 2018; Qenani, MacDougall, \& Sexton 2014). Excellent academic performance does not predict high employability of undergraduate students. They are required to be more dynamic and make better use of their time and effort to explore their career interests and continue to develop their skills for future employment (Niemela, 2016; Pinto \& Ramalheira, 2017; Sin, Tavares, \& Amaral, 2016).

The $\mathrm{H}^{3}$ of this study was supported and indicated that undergraduates who have high level of selfefficacy tend to have better perception of employability. This empirical finding is consistent with previous studies and shows that statistically positive self-efficacy is correlated with the perceived employability or employability of individuals (Berntson, Naswall, \& Sverke, 2008; Fugate, Kinicki, \& Ashforth, 2004; Sarkar, Overton, Thompson, \& Rayner, 2017). Individuals will be influenced by mastery experiences, vicarious experience, and social persuasion of peers and others (Dacre Pool \& Sewell, 2007). Such social influences will inspire and encourage them to put more effort efforts to pursue their future career goals. For example, offering undergraduates the opportunity to participate in project planning, public speaking and consulting with external agencies can improve their selfefficacy and perceived employability. Undergraduates are able to gain mastery experiences or vicarious experiences from those practical activities (Rufai \& Rashid, 2015). These career development learning foster a strong sense of efficacy belief for undergraduates and change their perception of employability.

However, current research has shown that self-efficacy does not mediate the relationship between perceived social support and perceived employability among undergraduates. Hui and Lent (2018) explained that people who have sufficient social support are motivated to pursue a personal interest in their careers, but that social support does not help them secure a job in the future. For example, a psychology graduate may receive adequate support from his or her parents to choose psychology as a major at university or pursue a career in psychology, but the graduate may lack some of the abilities, skills or knowledge to become a registered psychologist. Secondly, social supports are recognized as a form of protective resource that enables individuals to cope with stress, depression, burnout, and other psychological disorders (Wang, Hsieh, Assari, Gaskin, \& Rost, 2018). Social supports are essential to provide an emotional balance to individuals rather than directly increasing the level of self-efficacy and improving the employability of individuals (Stallman, Ohan, \& Chiera, 2018; Tran, 2013).

It should be noted that the current study confirmed the mediating effect of self-efficacy on the relationship between self-managed career behavior and perceived employability. In particular, a 
person's personal characteristics will influence his or her efficacy belief and this belief will lead to a desirable or undesirable outcome (Lent et al., 1994). Undergraduate students who are actively engaged in self-management in their career behavior in universities, for example by collecting career information and seeking career advice, developing social networks, acquiring internships and parttime work experiences, and improving skills and competencies, will develop a stronger self-efficacy compared to others (Koloba, 2017; Sin, Tavares, \& Amaral, 2016). Therefore, such a strong belief in efficacy will improve their employability perception (Gbadamosi, Evans, Richardson, \& Ridolfo, 2015).

\section{Implications}

The findings of the current research can make a significant contribution to CareerEDGE's employability model (Pool \& Sewell, 2007). According to Watt (2006), the CareerEDGE model's construct of career development learning emphasizes career education learning, which refers to planned curriculum activities that aim to develop self-awareness, awareness of opportunities, learning about decision-making and transition learning, to improve their employability. However, this study has brought a different perspective to the construct of career development learning by emphasizing the importance of self-managed career behavior. The self-managed career behavior of a person is equally important in contributing to the undergraduate's perceived employability.

Secondly, research findings are important for strengthening and encouraging undergraduate students to develop self-managed career behavior while pursuing their studies at universities. Selfmanaged career behaviors, such as career goal planning and the implementation of career tactics, are important for improving the employability of undergraduate students. Career planning and tactics such as expanding a person's social network to seek career and employment advice, and actively participating in various events or activities, unlocking personal strength and potential to enhance undergraduate is perception of employability (Niemela, 2016, Pinto \& Ramalheira, 2017). In addition, it is important to highlight the role of parents in developing undergraduate self-managed career behavior and self-efficacy. Parents play a central role in instilling a proactive value and developing the self-regulating behavior of children during the adolescent stage of development (Jittaseno \& Varma, 2017). Current research shows that self-efficacy is the main mediator of employability perceived by undergraduates. It is essential for parents to provide children with adequate support and resources at this stage to develop their self-efficacy and ensure their employability in the future.

In addition, the current findings also provide useful information on the management of higher education institutions in the development of an effective program/module framework to improve the employability of undergraduate students. The Malaysian government has urged local universities and colleges to initiate various programs to produce balanced and holistic undergraduates who are competent theoretically and practically in pursuing their future career (The Star, 2018). For example, the Ministry of Higher Education (MOHE) has put in place a new grading system in universities, the iCGPA program. This grading system is designed to evaluate not only the student's academic competence, but also his or her technical abilities (Tang et al., 2018). Technical skills such as language proficiency, critical thinking skills, problem-solving skill, and leadership skill. In addition, one of the 
goals set out in the Malaysian Higher Education Blueprint (MHEB) 2015-2025 is to improvise the MPU framework and the entrepreneurship program. The initiatives aim to develop students' entrepreneurial skills and other related competencies to ensure their career success and employability. The learning outcomes of subject modules should focus on the development of proactive and responsible behavior of undergraduate students, which is important to foster selfmanaged career behavior and employability in their career development process.

In addition, the findings of the current research are important for business organizations to collaborate with higher education institutions to develop undergraduates' career self-management behaviors. Many organizations have started to organize various career preparation workshops and seminars to boost up the competencies of the undergraduate's which are important for future employability. For example, several organizations participated in the Fourth Industrial Revolution Conference, in 2019, at HELP University (HELP University, 2019). The main objective of the conference is to provide a platform for university students to make them aware of the fourth trend of the industrial revolution in the business world. In this way, graduates will be better prepared to meet the expectations of future employers and increase the productivity of the company.

\section{Limitations and Future Research Suggestions}

The majority of respondents come from the private university $(65.4 \%)$, while those from the public university (34.6\%). This potentially influences the representativeness of the samples in generalizing the entire student population in Malaysia. To fill the gaps in the current employability literature, future researchers are encouraged to conduct qualitative research instead of quantitative research. Qualitative research helps us to better understand the perception of employability by undergraduates ' in Malaysia (Fusch \& Ness, 2015). In addition, future studies may consider examining demographic factors as moderating variables. It is essential to include demographic variables such as gender, years of study and enrolled programs, as they may offer different interaction effects that can help practitioners and researchers to understand the direct and indirect predicting effects of perceived employability.

\section{Conclusion}

The purpose of this study is to investigate the relationship between perceived social support, selfmanaged career behaviour, self-efficacy, and perceived employability among undergraduates. There are some major research findings in the current study. Firstly, the present study found that there is no significant positive relationship between perceived social support and perceived employability among undergraduates. Secondly,

self-managed career behavior was positively and significantly correlated with perceived employability. In addition, the findings also shown that there is mediating effect of self-efficacy to mediate the relationship between self-managed career behavior and perceived employability. The present study seeks to contribute to the development of CareerEDGE mdel by providing a different perspective to the construct of career development learning by emphasising the importance of selfmanaged career behaviour and confirmed that self-managed career behavior is the significant predictor of perceived employability among undergraduates. In addition, the higher education 
INTERNATIONAL JOURNAL OF ACADEMIC RESEARCH IN BUSINESS AND SOCIAL SCIENCES Vol. 9, No. 6, June, 2019, E-ISSN: 2222-6990 @ 2019 HRMARS

institutions could strengthen and encourage undergraduates' self-managed career behavior in universities via extra co-curriculum programs, which will effectively contribute to the implementation of iCGPA grading system and achievement the goals of Malaysian Higher Education Blueprint 20152025. Undergraduates can learn how to prepare themselves for the challenges they will face in job search. They are become more aware of what areas that they should focus on in order to improve their employability in the future. Finally, it is suggested that future researchers to conduct qualitative research in order to have better understand the perception of employability of among undergraduates.

\section{References}

Abarghuei, A., \& Ghavam, E. (2016). The causal relationship of the social support and maladaptive perfectionism with the academic burnout mediated by the self-efficacy among undergraduate students of Shahid Chamran University. Mediterranean Journal of Social Sciences, 7(4 S1), 11. doi: 10.5901/mjss.2016.v7n4S1p11

Ballout, H. I. (2007). Career success: The effects of human capital, person-environment fit and organizational support. Journal of Managerial Psychology, 22(8), 741-765. doi: 10.1108/02683940710837705

Bandura, A. (1986). Social foundations of thought and action: A social cognitive theory. Englewood Cliffs, NJ: Prentice-Hall.

Baruch, Y., \& Bozionelos, N. (2011). Career issues. Handbook of Industrial and Organisational Psychology, 2, 66-113

Batistic, S., \& Tymon, A. (2017). Networking behaviour, graduate employability: A social capital perspective. Education + Training, 59(4), 374-388. doi: 10.1108/ET-06-2016-0100 \

Berntson, E., Naswall, K., \& Sverke, M. (2008). Investigating the relationship between employability and self-efficacy: A cross-lagged analysis. European Journal of Work and Organizational Psychology, 17(4), 413-425. doi: 10.1080/13594320801969699

Bhandari, H., \& Yasunobu, K. (2009). What is social capital? A comprehensive review of the concept. Asian Journal of Social Science, 37(3), 480-510. doi: 10.1163/156853109X436847

Bourdieu, P. (1986) The forms of capital. In: Richardson JG (ed.) Handbook of Theory and Research for the Sociology of Education. New York: Greenwood.

Bridgstock, R. (2009). The graduate attributes we've overlooked: Enhancing graduate employability through career management skills. Higher Education Research \& Development, 28(1), 31-44. doi: 10.1080/07294360802444347

Chen, G., Gully, S. M., \& Eden, D. (2001). Validation of a new general self-efficacy scale. Organizational Research Methods, 4(1), 62-83. doi: 10.1177/109442810141004

Chiesa, R., Fazi, L., Guglielmi, D., \& Mariani, M. (2018). Enhancing sustainability: Psychological capital, perceived employability, and job insecurity in different work contract conditions. Sustainability, 10(7), 2475. doi: 10.3390/su10072475

Cohen, J. A. (1992). A power primer. Psychological Bulletin, 112, 155-159.

Clements, A. J., \& Kamau, C. (2018). Understanding students' motivation towards proactive career behaviours through goal-setting theory and the job demands-resources model. Studies in Higher Education, 43(12), 2279-2293. doi: 10.1080/03075079.2017.1326022 
INTERNATIONAL JOURNAL OF ACADEMIC RESEARCH IN BUSINESS AND SOCIAL SCIENCES

Vol. 9, No. 6, June, 2019, E-ISSN: 2222-6990 @ 2019 HRMARS

Pool, D. L. D., \& Sewell, P. (2007). The key to employability: Developing a practical model of graduate employability. Education + Training, 49(4), 277-289. doi:

10.1108/00400910710754435

De Cuyper, N., \& De Witte, H. (2010). Temporary employment and perceived employability:

Mediation by impression management. Journal of Career Development, 37(3), 635-652. doi: $10.1177 / 089484530$

9357051

Dickinson, J. (2007). An examination of applicability of social cognitive career theory for African American college students (Doctoral dissertation). Retrieved from https://etd.ohiolink.edu/

Donald, W. E., Ashleigh, M. J. \& Baruch, Y. (2018). Students' perceptions of education and employability: Facilitating career transition from higher education into the labor market. Career Development International, 23(5), 513-540. doi: 10.1108/CDI-09-2017-0171

Fawehinmi, O. O. \& Yahya, K. K. (2018). Investigating the linkage between proactive personality and social support on career adaptability amidst undergraduate students. Journal of Business and Social Review in Emerging Economies, 4(1), 81-92. doi: 10.26710/jbsee.v4i1.370

Fornell, C. \& Larcker, D. (1981). Evaluating structural equation models with unobservable variables and measurement error. Journal of Marketing Research, 18(3), 39-50. doi: $10.1177 / 002224378101800104$

Fusch, P. I. \& Ness, L. R. (2015). Are we there yet? Data saturation in qualitative research. The Qualitative Report, 20(9), 1408-1416.

Fugate, M., Kinicki, A. J. \& Ashforth, B. E. (2004). Employability: A psycho-social construct, its dimensions, and applications. Journal of Vocational Behaviour, 65, 14-38. doi: 10.1016/j.jvb.2003.10.005.

Gbadamosi, G., Evans, C., Richardson, M. \& Ridolfo, M. (2015). Employability and students' parttime work in the UK: Does self-efficacy and career aspiration matter?. British Educational Research Journal, 41(6), 1086-1107. doi: 10.1002/berj.3174

Gokuladas, V. K. (2011). Predictors of employability of engineering graduates in campus recruitment drives of Indian software services companies. International Journal of Selection and Assessment, 19(3), 313-319. doi: 10.1111/j.1468-2389.2011.00560.x

Hair, J. F., Hult, G. T. M., Ringle, C. M. \& Sarstedt, M. (2017). A primer on Partial Least Squares Structural Equation modelling (2nd ed.). Thousand Oaks: SAGE Publications.

HELP University. (2019). Accelerating Malaysian business and the workforce into industrial revolution 4.0. Retrieved from https://www.help.edu.my/accelerating-malaysian-businessand-the-workforce-into-industrial-revolution-4-0/

Hillage, J. \& Pollard, E. (1998). Employability: Developing a framework for policy analysis. London: DfEE.

Hui, T., Yuen, M. \& Chen, G. (2018). Career adaptability, self-esteem, and social support among Hong Kong university students. The Career Development Quarterly, 66(2), 94-106. doi: 10.1002/cdq.12118.

Hui, K. \& Lent, R. W. (2018). The roles of family, culture, and social cognitive variables in the career interests and goals of Asian American college students. Journal of Counseling Psychology, 65(1), 98. doi: 10.1037 
INTERNATIONAL JOURNAL OF ACADEMIC RESEARCH IN BUSINESS AND SOCIAL SCIENCES

Vol. 9, No. 6, June, 2019, E-ISSN: 2222-6990 @ 2019 HRMARS

/cou0000235

Hogan, M. J., Parker, J. D., Wiener, J., Watters, C., Wood, L. M. \& Oke, A. (2010). Academic success in adolescence: Relationships among verbal IQ, social support and emotional intelligence. Australian Journal of Psychology, 62(1), 30-41. doi: 10.1080/00049530903312881

International Labour Organisation. (2018). Unemployment, youth total (\% of total labour force ages 15-24). Retrieved from https://data.worldbank.org/indicator/SL.UEM.1524.ZS?end=2017\&name_desc=false\& start $=1991$

Isik, E. (2013). Perceived social support and locus of control as the predictors of vocational outcome expectations. Educational Sciences: Theory and Practice, 13(3), 1426-1430.

Jittaseno, P. \& Varma, P. (2017). Influence of parenting styles on self-regulated learning behavior mediated by self-efficacy and intrinsic value. Scholar: Human Sciences, 8(2).

Kinnunen, U., Makikangas, A., Mauno, S., Siponen, K. \& Natti, J. (2011). Perceived employability: Investigating outcomes among involuntary and voluntary temporary employees compared to permanent employees. Career Development International, 16(2), 140-160. doi: 10.1108/13620431111115604

Kline, R. B. (2011). Principles and practice of structural equation modeling (3rd ed.). Guilford publications.

Koloba, H. A. (2017). Perceived employability of university students in South Africa. Is it related to employability skills?. International Journal of Social Sciences and Humanity Studies, 9(1), 7390.

Lent, R. W., Brown, S. D. \& Hackett, G. (1994). Toward a unifying social cognitive theory of career and academic interest, choice, and performance. Journal of Vocational Behavior, 45(1), 79122. doi: $10.1006 / j v b e .1994 .1027$

Li, J., Han, X., Wang, W., Sun, G. \& Cheng, Z. (2018). How social support influences university students' academic achievement and emotional exhaustion: The mediating role of selfesteem. Learning and Individual Differences, 61, 120-126. doi: 10.1016/j.lindif.2017.11.016

Niemela, K. (2016). Employability of a business graduate - Skills and experience required when entering the job market. Retrieved from https://www.theseus.fi/handle/10024/110280.

Mcluckie, A., Matheson, K. M., Landers, A. L., Landine, J., Novick, J., Barrett, T. \& Dimitropoulos, G. (2018). The relationship between psychological distress and perception of emotional support in medical students and residents and implications for educational institutions. Academic Psychiatry, 42(1), 41-47.

MIDF. (2018). Economic review. 2017 labour market. Retrieved from https://www.midf.com.my/images/Downloads/Research/Econs-Msia-2017-Youth-UE-MIDF030518.pdf

Montes-Berges, B. \& Augusto, J. M. (2007). Exploring the relationship between perceived emotional intelligence, coping, social support and mental health in nursing students. Journal of Psychiatric and Mental Health Nursing, 14(2), 163-171. doi: 10.1111/j.1365850.2007.01059.x

Orpen, C. (1994). The effects of organizational and individual career management on career success. International Journal of Manpower, 15(1), 27-37. doi: 10.1108/01437729410053617 
INTERNATIONAL JOURNAL OF ACADEMIC RESEARCH IN BUSINESS AND SOCIAL SCIENCES

Vol. 9, No. 6, June, 2019, E-ISSN: 2222-6990 @ 2019 HRMARS

Pinto, L. H. \& Ramalheira, D. C. (2017). Perceived employability of business graduates: The effect of academic performance and extracurricular activities. Journal of Vocational Behavior, 99, 165178. doi: 10.1016/j.jvb.2017.01.005

Poon, J. (2012). Real estate graduates' employability skills: The perspective of human resource managers of surveying firms. Property Management, 30(5), 416-434.

Potgieter, I. (2012). The relationship between the self-esteem and employability attributes of postgraduate business management students. SA Journal of Human Resource Management, 10(2), 1-15.

Preacher, K. J. \& Hayes, A. F. (2008). Asymptotic and resampling strategies for assessing and comparing indirect effects in multiple mediator models. Behavior Research Methods, 40(3), 879-891. doi: $10.3758 /$

BRM.40.3.879

Qenani, E., MacDougall, N. \& Sexton, C. (2014). An empirical study of self-perceived employability: Improving the prospects for student employment success in an uncertain environment. Active Learning in Higher Education, 15(3), 199-213. doi: 10.1177/1469787414544875

Rothwell, A., Herbert, I., \& Rothwell, F. (2008). Self-perceived employability: Construction and initial validation of a scale for university students. Journal of Vocational Behavior, 73(1), 1-12. doi: 10.1016/j.jvb.2007.12.001

Rothwell, A., Jewell, S. \& Hardie, M. (2009). Self-perceived employability: Investigating the responses of post-graduate students. Journal of Vocational Behavior, 75(2), 152-161. doi: 10.1016/j.jvb.2009.05.002

Rufai, A. U. \& Rashid, A. B. M. (2015). Developing a sustainable practical model of graduate employability for higher education. International Journal of Education and Literacy Studies, 3(1), 42-51.

Ryan, L., Sales, R., Tilki, M. \& Siara, B. (2008). Social networks, social support and social capital: The experiences of recent Polish migrants in London. Sociology, 42(4), 672-690. doi: $10.1177 / 0038038508091622$

Sarkar, M., Overton, T., Thompson, C. \& Rayner, G. (2017). Undergraduate science students' perceptions of employability: Efficacy of an intervention. International Journal of Innovation in Science and Mathematics Education (formerly CAL-laborate International), 25(5).

Shafie, L. A. \& Nayan, S. (2010). Employability awareness among Malaysian undergraduates. International Journal of Business and Management, 5(8), 119.

Sin, C., Tavares, O. \& Amaral, A. (2016). Who is responsible for employability? Student perceptions and practices. Tertiary Education and Management, 22(1), 65-81. doi: 10.1080/13583883.2015.1134634

Stallman, H. M., Ohan, J. L. \& Chiera, B. (2018). The role of social support, being present, and selfkindness in university student psychological distress. Australian Psychologist, 53(1), 52-59. doi: 10.1111/ap.12271

Su, W. \& Zhang, M. (2015). An integrative model for measuring graduates' employability skills - A study in China. Cogent Business \& Management, 2(1), 1060729. doi: 10.1080/23311975.2015.1060729 
INTERNATIONAL JOURNAL OF ACADEMIC RESEARCH IN BUSINESS AND SOCIAL SCIENCES Vol. 9, No. 6, June, 2019, E-ISSN: 2222-6990 @ 2019 HRMARS

Tang, J. R., Tan, E. T., Che'Rus, R., Azman, M. N. A. \& Hanapi, Z. (2018). Study on the perception of lecturers from two Malaysian universities on Integrated Cumulative Grade Point Average (iCGPA) assessment. International Journal of Academic Research in Businessand Social Sciences, 8(7), 300-311. doi: 10.6007/ IJARBSS/v8-i7/4342

The Star. (2018). Redesigning Malaysia's higher education system. Retrieved from https://www.thestar.com. my/news/education/2018/05/06/redesigning-malaysias-higher-education-system/

Tuah, V. (2018). Job market remain healthy, but youth employment rate still remain high. Retrieved from https://www.pressreader.com/malaysia/the-borneo-post/20180504/282978220625461

Thang, P. V. M., \& Wongsurawat, W. (2016). Enhancing the employability of IT graduates in Vietnam. Higher Education, Skills and Work-Based Learning, 6(2), 146-161. doi: 10.1108/HESWBL-07-2015-0043

Tran, T. T. J. (2013). Counting the uncounted: Rumors, corruption and luck in job seeking by Vietnamese university graduates. Journal of Asian Critical Education, 2, 3-12.

Vargas, R. (2018). Self-perceived employability in Spain. Education + Training, 60(3), 226-237. doi: 10.1108/ET03-2017-0037

Watts, A. G. (2006). Career development learning and employability. The Higher Education Academy, York

Wang, Y. F., \& Tsai, C. T. (2014). Employability of hospitality graduates: Student and industry perspectives. Journal of Hospitality \& Tourism Education, 26(3), 125-135. doi: 10.1080/10963758.2014.935221

Wang, J. L., Hsieh, H. F., Assari, S., Gaskin, J. \& Rost, D. H. (2018). The protective effects of social support and engagement coping strategy on the relationship between perceived discrimination and psychological distress among Chinese migrant children. Youth \& Society, 50(5), 593-614. doi: 10.1177/0044118x15619 804

Wille, B., De Fruyt, F. \& Feys, M. (2013). Big five traits and intrinsic success in the new career era: A 15 year longitudinal study on employability and work-family conflict. Applied Psychology: An International Review, 62, 124-156. doi: 10.1111/j.1464-0597.2012.00516.x

Wong. S. C. \& Quek, L. S. (2015). Factors affecting individual career management among undergraduates in higher education institutions. International Journal of Academic Research in Business and Social Sciences, 5(10), 56-68. doi: 10.6007/IJARBSS/v5-i10/1842

Yorke, M. \& Knight, P. (2004). Learning, Curriculum and Employability in Higher Education, Routledge Falmer, London.

Zimet, G. D., Dahlem, N. W., Zimet, S. G. \& Farley, G. K. (1988). The multidimensional scale of perceived social support. Journal of Personality Assessment, 52(1), 30-41. doi: 10.1207/s15327752jpa5201_2 
INTERNATIONAL JOURNAL OF ACADEMIC RESEARCH IN BUSINESS AND SOCIAL SCIENCES Vol. 9, No. 6, June, 2019, E-ISSN: 2222-6990 @ 2019 HRMARS

Table 3.1 Result of Measurement Model

\begin{tabular}{|c|c|c|c|c|}
\hline Constructs & Items & Loadings & AVE & Cronbach's Alpha \\
\hline \multirow[t]{10}{*}{ Perceived Social Supports } & PSS1 & 0.781 & 0.530 & 0.898 \\
\hline & PSS2 & 0.778 & & \\
\hline & PSS4 & 0.55 & & \\
\hline & PSS5 & 0.765 & & \\
\hline & PSS6 & 0.777 & & \\
\hline & PSS7 & 0.720 & & \\
\hline & PSS8 & 0.505 & & \\
\hline & PSS9 & 0.802 & & \\
\hline & PSS10 & 0.764 & & \\
\hline & PSS12 & 0.771 & & \\
\hline \multirow[t]{7}{*}{ Self-Managed Career Behaviour } & SM1 & 0.766 & 0.525 & 0.848 \\
\hline & SM2 & 0.791 & & \\
\hline & SM3 & 0.743 & & \\
\hline & SM4 & 0.69 & & \\
\hline & SM6 & 0.726 & & \\
\hline & SM7 & 0.63 & & \\
\hline & SM8 & 0.713 & & \\
\hline \multirow[t]{8}{*}{ Self-Efficacy } & SE1 & 0.648 & 0.571 & 0.892 \\
\hline & SE2 & 0.774 & & \\
\hline & SE3 & 0.753 & & \\
\hline & SE4 & 0.765 & & \\
\hline & SE5 & 0.764 & & \\
\hline & SE6 & 0.803 & & \\
\hline & SE7 & 0.748 & & \\
\hline & SE8 & 0.779 & & \\
\hline \multirow[t]{7}{*}{ Perceived Employability } & PE2 & 0.663 & 0.505 & 0.837 \\
\hline & PE3 & 0.697 & & \\
\hline & PE5 & 0.705 & & \\
\hline & PE6 & 0.672 & & \\
\hline & PE7 & 0.733 & & \\
\hline & PE8 & 0.77 & & \\
\hline & PE9 & 0.726 & & \\
\hline
\end{tabular}

Note: PSS3, PSS11, SM5, PE1, and PE4 were deleted due to low loadings. 
INTERNATIONAL JOURNAL OF ACADEMIC RESEARCH IN BUSINESS AND SOCIAL SCIENCES Vol. 9, No. 6, June, 2019, E-ISSN: 2222-6990 (C) 2019 HRMARS

Table 3.2 Discriminant Validity using Fornell and Lacker Criterion

\begin{tabular}{|c|c|c|c|c|}
\hline & $\begin{array}{c}\text { Perceived } \\
\text { Employability }\end{array}$ & $\begin{array}{c}\text { Perceived } \\
\text { Social } \\
\text { Supports }\end{array}$ & Self-Efficacy & $\begin{array}{c}\text { Self-Managed } \\
\text { Career } \\
\text { Behaviour }\end{array}$ \\
\hline $\begin{array}{l}\text { Perceived } \\
\text { Employability }\end{array}$ & 0.71 & & & \\
\hline $\begin{array}{l}\text { Perceived Social } \\
\text { Supports }\end{array}$ & 0.3 & 0.728 & & \\
\hline Self-Efficacy & 0.57 & 0.285 & 0.755 & \\
\hline $\begin{array}{l}\text { Self-Managed Career } \\
\text { Behaviour }\end{array}$ & 0.556 & 0.397 & 0.648 & 0.724 \\
\hline
\end{tabular}

Notes:Diagonals represent the square root of the AVE while the off-diagonals represent the correlations.

Table 3.3 Discriminant Validity using HTMT Criterion

\begin{tabular}{|c|c|c|c|c|}
\hline & $\begin{array}{c}\text { Perceived } \\
\text { Employability }\end{array}$ & $\begin{array}{c}\text { Perceived Social } \\
\text { Supports }\end{array}$ & Self-Efficacy & $\begin{array}{c}\text { Self-Managed Career } \\
\text { Behaviour }\end{array}$ \\
\hline $\begin{array}{l}\text { Perceived } \\
\text { Employability }\end{array}$ & & & & \\
\hline $\begin{array}{l}\text { Perceived } \\
\text { Social } \\
\text { Supports } \\
\end{array}$ & $\begin{array}{c}0.341 \\
\mathrm{Cl} .90(0.227,0.455)\end{array}$ & & & \\
\hline Self-Efficacy & $\begin{array}{c}0.639 \\
\mathrm{Cl} .90(0.547,0.715)\end{array}$ & $\begin{array}{c}0.314 \\
\mathrm{Cl} .90(0.195 \\
0.438)\end{array}$ & & \\
\hline $\begin{array}{l}\text { Self- } \\
\text { Managed } \\
\text { Career } \\
\text { Behaviour }\end{array}$ & $\begin{array}{c}0.645 \\
\text { Cl.90 (0.554 0.719) }\end{array}$ & $\begin{array}{c}0.451 \\
\mathrm{Cl} .90(0.329 \\
0.560)\end{array}$ & $\begin{array}{c}0.746 \\
\mathrm{Cl} .90(0.669, \\
0.807)\end{array}$ & \\
\hline
\end{tabular}


INTERNATIONAL JOURNAL OF ACADEMIC RESEARCH IN BUSINESS AND SOCIAL SCIENCES Vol. 9, No. 6, June, 2019, E-ISSN: 2222-6990 @ 2019 HRMARS

Table 4.1 Summary of Structural Model

\begin{tabular}{|c|c|c|c|c|c|c|c|c|c|}
\hline Hypothesis & Relationships & $\begin{array}{l}\text { Std } \\
\text { Beta }\end{array}$ & $\begin{array}{l}\text { Std. } \\
\text { Error }\end{array}$ & t-value & Decision & $\mathbf{R}^{2}$ & $f^{2}$ & $\mathbf{Q}^{2}$ & $q^{2}$ \\
\hline $\mathrm{H} 1$ & $\begin{array}{l}\text { Perceived } \\
\text { Social } \\
\text { Supports } \rightarrow \\
\text { Perceived } \\
\text { employability }\end{array}$ & 0.083 & 0.062 & $1.337^{*}$ & Rejected & 0.421 & 0.009 & 0.176 & 0.002 \\
\hline $\mathrm{H} 2$ & $\begin{array}{l}\text { Self- } \\
\text { Managed } \\
\text { Career } \\
\text { Behaviour } \rightarrow \\
\text { Perceived } \\
\text { employability }\end{array}$ & 0.291 & 0.065 & $4.442 * *$ & Supported & & 0.074 & & 0.02 \\
\hline H3 & $\begin{array}{l}\text { Self-Efficacy } \\
\rightarrow \text { Perceived } \\
\text { employability }\end{array}$ & 0.358 & 0.069 & $5.227 * *$ & Supported & 0.39 & 0.122 & 0.22 & 0.07 \\
\hline
\end{tabular}

Note: ${ }^{* *} p<0.01, p>0.05$ 
INTERNATIONAL JOURNAL OF ACADEMIC RESEARCH IN BUSINESS AND SOCIAL SCIENCES Vol. 9, No. 6, June, 2019, E-ISSN: 2222-6990 @ 2019 HRMARS

Table 4.2 Mediation Analysis

\begin{tabular}{|c|c|c|c|c|c|c|c|}
\hline \multirow[t]{2}{*}{ Hypothesis } & \multirow[t]{2}{*}{ Relationships } & \multirow{2}{*}{$\begin{array}{l}\text { Std. } \\
\text { Beta }\end{array}$} & \multirow{2}{*}{$\begin{array}{l}\text { Std. } \\
\text { Error }\end{array}$} & \multirow[t]{2}{*}{ t-value } & \multicolumn{2}{|c|}{$\begin{array}{c}\text { Confidence } \\
\text { Interval }\end{array}$} & \multirow[t]{2}{*}{ Decision } \\
\hline & & & & & LL & UL & \\
\hline $\mathrm{H} 4$ & $\begin{array}{l}\text { Self-efficacy } \\
\text { mediates the } \\
\text { relationship } \\
\text { between } \\
\text { perceived social } \\
\text { supports and } \\
\text { perceived } \\
\text { employability }\end{array}$ & 0.012 & 0.02 & $0.583^{*}$ & -0.031 & 0.049 & Rejected \\
\hline H5 & $\begin{array}{l}\text { Self-efficacy } \\
\text { mediates the } \\
\text { relationship } \\
\text { between self- } \\
\text { managed career } \\
\text { behaviour and } \\
\text { perceived } \\
\text { employability }\end{array}$ & 0.228 & 0.049 & $4.684 * *$ & 0.135 & 0.326 & $\begin{array}{c}\text { Supporte } \\
\text { d }\end{array}$ \\
\hline
\end{tabular}

Note: ${ }^{* *} p<0.01, * p>0.0$ 